Original Article

\title{
Participation in physical activity for adolescents with disabilities: Parents' perspective
}

\author{
Dena Widyawan ${ }^{1}$ \\ ${ }^{1}$ Program Studi Pendidikan Jasmani Kesehatan dan Rekreasi, STKIP Situs Banten, Indonesia \\ dena.widyawan@stkipsitusbanten.ac.id ${ }^{l}$
}

\begin{abstract}
ABSTRAK
Tujuan penelitian ini untuk mengambarkan peran orang tua dalam mempromosikan aktivitas fisik anak remaja penyandang disabilitas serta mengambarkan persepsi tentang partisipasinya. Penelitian ini menggunakan desain deskriptif kualitatif. Prosedur sampel dengan menggunakan convenience sampling. Total 28 orang tua dari remaja penyandang disabilitas berusia dua belas - enam belas tahun. Analisis data menggunakan analisis konten, dengan pengembangan kategori induktif menggunakan aplikasi Nvivo 11. Selama delapan minggu data dikumpulkan dari Januari hingga Februari 2020. Semua sampel menjelaskan betapa banyak tantangan berpartisipasi dalam aktivitas fisik remaja penyandang disabilitas. Bagaimanapun, orang tua ingin melihat anak-anaknya lebih berpartisipasi dalam aktivitas fisik, tetapi menganggap promosi aktivitas fisik sebagai tugas yang sangat berat yang sulit untuk ditangani sendiri. Simpulan bahwa promosi kebiasaan beraktivitas fisik pada remaja penyandang disabilitas perlu diutamakan, bahwa dukungan yang diberikan perlu disesuaikan dengan kebutuhan remaja dan keluarganya serta adanya upaya kolaboratif serta dukungan semua pihak.
\end{abstract}

Kata kunci: remaja, aktivitas fisik, orang tua, penyandang disabilitas.

\section{ABSTRACT}

This study is to describe the role of parents in promoting the physical activity of adolescents with disabilities and to describe their perceptions of participation. This study used a qualitative descriptive design. Sample procedure using convenience sampling. A total of 28 parents of youth with disabilities aged twelve - sixteen years. Data analysis used content analysis, with the development of inductive categories using Nvivo 11 software. For eight weeks, data were collected from January to February 2020. All samples explained how many challenges involved participating in physical activities of adolescents with disabilities. After all, parents would like to see their children participating in more physical activity, but consider the promotion of physical activity to be a very demanding task that is difficult to handle alone. The finding is that the promotion of physical activity habits among adolescents with disabilities needs to be prioritized, that the support provided needs to be tailored to the needs of adolescents and their families as well as collaborative efforts and support from all parties. 
41 | Dena Widyawan ${ }^{1}$

Participation in physical activity for adolescents with disabilities:

Parents' perspective

Key words: adolescent, physical activity, parents, persons with disabilities

Received: 02-06-2021; Accepted: 12-06-2021; Published: 20-06-2021

(c) 2021 Universitas Suryakancana

e-ISSN: 2721-7175(online) p-ISSN: 2089-2341 (cetak)

\section{PENDAHULUAN}

Tingkat penurunan aktivitas fisik dan perilaku menetap meningkat sebelum anak mencapai masa remaja (Basterfield et al., 2011) menyebabkan peningkatan risiko gangguan kesehatan (Biddle \& Asare, 2011). Anak-anak dan remaja penyandang disabilitas umumnya memiliki tingkat aktivitas fisik yang lebih rendah dibandingkan dengan teman sebaya yang normal, dan tingkat aktivitas fisiknya menurun seiring bertambahnya usia (Mccoy \& Morgan, 2019). Oleh karena itu, kebiasaan aktivitas fisik remaja perlu lebih dipahami dan partisipasi dalam aktivitas fisik harus ditingkatkan. Orang tua sangat penting dalam konteks ini (Solihin et al., 2020; Widyawan \& Sina, 2021), dan pengaruhnya penting pada kebiasaan aktivitas fisik anak, yang dibentuk sepanjang masa kanak-kanak dan remaja (Cheng et al., 2014). Perannya sangat penting dalam meningkatkan partisipasi remaja dalam aktivitas fisik karena memiliki pengetahuan unik tentang perilaku, keinginan, dan kebutuhan remaja (Afriyuandi, 2018; Laksana \& Sumirat, 2020).

Partisipasi dalam aktivitas fisik dapat menjadi tantangan bagi remaja penyandang disabilitas. Faktanya, para remaja sering melaporkan bahwa aktivitas fisik adalah aktivitas rekreasi yang paling tidak disukai (Potvin et al., 2013). Hal ini bisa terjadi oleh banyak faktor, karena gangguan fisik dan mekanisme sosio-perilaku mempengaruhi partisipasinya; misalnya, sering mengalami kesulitan berkomunikasi, interaksi sosial yang terbatas, atau keterampilan bergerak yang tertunda atau terganggu (Widyawan, 2020). Penelitian sebelumnya menggambarkan persepsi remaja tentang partisipasi dalam aktivitas fisik, mengungkapkan partisipasi bersyarat dalam aktivitas fisik. Para remaja dalam penelitian tersebut mengungkapkan berbagai kondisi individu untuk berpartisipasi dalam aktivitas fisik, yang meliputi kompetensi dan kepercayaan diri, motivasi, penyesuaian terhadap tuntutan eksternal, prediktabilitas aktivitas fisik, dan kebebasan memilih mengenai jenis aktivitas fisik, konteks aktivitas. Ungkapan 
42 | Dena Widyawan ${ }^{1}$

Participation in physical activity for adolescents with disabilities:

Parents' perspective

kondisi khusus orang yang khas dapat diartikan sebagai sarana remaja untuk mengontrol partisipasi dalam aktivitas fisik dan bahkan konteks aktivitas fisik. Dengan demikian, kegagalan untuk mengenali kondisi dan tuntutan setiap individu untuk berpartisipasi dalam aktivitas fisik dapat berdampak negatif pada kemampuan dan kemauan remaja untuk berpartisipasi. Menyadari dan mengenali kondisi spesifik individu dapat menjadi faktor kunci untuk mempromosikan serta membangun kebiasaan aktivitas fisik yang sehat.

Selain itu, dukungan orang tua penting bagi remaja penyandang disabilitas (Widyawan et al., 2020), karena mendapatkan dukungan yang lebih terbatas di luar keluarga, seperti terbatasnya kesempatan untuk berpartisipasi dalam aktivitas fisik, kurangnya teman sebaya sebagai mitra aktivitas, atau kurangnya instruktur terlatih saat berpartisipasi dalam kegiatan fisik yang terorganisir atau tidak terstruktur (Gregor et al., 2018). Kebutuhan akan dukungan orang tua dapat berlanjut hingga dewasa (Nichols et al., 2019). Dengan demikian, dukungan yang ditawarkan orang tua seringkali sangat penting bagi kemampuan dan kesediaan remaja untuk berpartisipasi dalam aktivitas fisik. Upaya orang tua untuk mendorong anak remaja berpartisipasi dalam aktivitas fisik sangat menuntut keterlibatan dirinya sendiri, yang dapat mempengaruhi kebiasaan aktivitas fisik seluruh keluarga (Ayvazoglu et al., 2015). Hal ini dapat berdampak pada partisipasi saudara kandung dalam kegiatan ekstrakurikuler (Wigston et al., 2015), serta membuat stres orang tua. Penelitian sebelumnya terutama berfokus pada perspektif orang tua tentang strategi, hambatan, dan fasilitator yang memengaruhi partisipasi anak dalam aktivitas fisik (Nichols et al., 2019). Namun, penelitian mendalam tentang persepsi orang tua tentang peran orang tua masih terbatas saat mempromosikan partisipasi dalam aktivitas fisik di kalangan remaja penyandang disabilitas. Tujuan penelitian ini untuk mengeksplorasi persepsi orang tua tentang partisipasi dalam aktivitas fisik di antara remaja penyandang disabilitas dan untuk menggambarkan peran orang tua dalam mempromosikan partisipasinya, termasuk tujuan penelitian berikut: pemikiran tentang menyesuaikan aktivitas fisik dengan kebiasaan remaja, peran orang tua dalam mempromosikan kebiasaan aktivitas fisik, dan faktor-faktor yang mempengaruhinya. 
43 | Dena Widyawan ${ }^{1}$

Participation in physical activity for adolescents with disabilities:

Parents' perspective

\section{METODE}

Penelitian ini menggunakan desain deskriptif kualitatif dengan menggunakan wawancara semi-terstruktur yang berfokus pada promosi partisipasi dalam aktivitas fisik pada remaja penyandang disabilitas dari perspektif orang tua. Wawancara semiterstruktur dalam konteks ini, karena memungkinkan tercakupnya tema-tema yang relevan untuk penelitian, serta memberikan fleksibilitas dalam format pertanyaan (Brinkmann \& Kvale, 2015).

Peserta direkrut menggunakan convenience sampling dengan mengirimkan surat undangan berisi informasi tentang penelitian kepada semua orang tua atau wali yang memenuhi kriteria inklusi: orang tua yang mempunyai anak yang menghadiri pusat rehabilitasi anak dan remaja di Provinsi Banten. Orang tua yang setuju untuk berpartisipasi dalam penelitian ini menyerahkan persetujuan melalui email. Para orang tua diberitahu bahwa partisipasinya bersifat sukarela dan kerahasiaan dijamin. Para peserta diyakinkan bahwa identitasnya akan ditangani secara rahasia dalam semua pelaporan penelitian. Dua puluh delapan orang tua, dua puluh lima ibu, dan tiga ayah dari remaja penyandang disabilitas berpartisipasi dalam penelitian ini.

Wawancara didasarkan pada panduan wawancara semi-terstruktur, yang terdiri dari pertanyaan-pertanyaan terbuka. Panduan wawancara dikembangkan untuk menangkap persepsi orang tua tentang keterlibatan dalam aktivitas fisik dan promosi peningkatan aktivitas fisik untuk remaja penyandang disabilitas. Selama delapan minggu data dikumpulkan dari Januari hingga Februari 2020. Topik mengenai aktivitas fisik secara umum dan kebiasaan aktivitas fisik keluarga, partisipasi remaja dalam aktivitas fisik, dan upaya orang tua ketika aktivitas fisik ditingkatkan dimasukkan (lihat Tabel 1). Sebelum penelitian, dua wawancara percontohan dilakukan untuk menguji dan meningkatkan validitas konstruk dari panduan wawancara. Setelah wawancara percontohan, panduan wawancara direvisi dan pertanyaan terbuka tentang tanggung jawab untuk mempromosikan kebiasaan aktivitas fisik yang sehat ditambahkan untuk lebih mencakup tujuan penelitian ini. 
44 | Dena Widyawan ${ }^{1}$

Participation in physical activity for adolescents with disabilities:

Parents' perspective

Tabel 1. Panduan wawancara

\begin{tabular}{|c|c|}
\hline Topik & Contoh pertanyaan \\
\hline $\begin{array}{l}\text { Pemikiran } \\
\text { aktivitas fisik }\end{array}$ & $\begin{array}{l}\text { Bagaimana bapak/ibu memandang kebiasaan } \\
\text { aktivitas fisik Anda dalam keluarga Anda? } \\
\text { Bagaimana Anda memandang partisipasi anak remaja } \\
\text { Anda dalam aktivitas fisik? (Kegiatan fisik sekolah } \\
\text { dan waktu senggang). Apakah kebiasaan aktivitas } \\
\text { fisik anak Anda berubah dari waktu ke waktu dan jika } \\
\text { ya, bagaimana caranya? }\end{array}$ \\
\hline $\begin{array}{l}\text { Mempromosikan } \\
\text { kebiasaan aktivitas fisik } \\
\text { untuk anak / remaja }\end{array}$ & $\begin{array}{l}\text { Siapa yang bertanggung jawab untuk } \\
\text { mempromosikan partisipasi dalam aktivitas fisik? } \\
\text { Bagaimana Anda memengaruhi kebiasaan aktivitas } \\
\text { fisik anak Anda? Bagaimana Anda mendorong anak } \\
\text { Anda untuk aktif secara fisik? Apa yang berhasil / } \\
\text { kurang baik? Apa yang secara positif / negatif } \\
\text { mempengaruhi kebiasaan aktivitas fisik anak Anda? }\end{array}$ \\
\hline $\begin{array}{lr}\text { Dukungan } & \text { dalam } \\
\text { promosi } & \text { kebiasaan } \\
\text { aktivitas fisik } & \end{array}$ & $\begin{array}{l}\text { Jenis dukungan apa yang bapak/ibu inginkan untuk } \\
\text { anak Anda dalam konteks aktivitas fisik? Jenis } \\
\text { dukungan apa yang bapak/ibu inginkan sebagai orang } \\
\text { tua ketika mempromosikan partisipasi dalam aktivitas } \\
\text { fisik untuk anak Anda? Seperti apa dukungannya? } \\
\text { Pernahkah Anda menerima atau ditawari dukungan } \\
\text { dalam pertanyaan yang berkaitan dengan aktivitas } \\
\text { fisik untuk anak Anda? }\end{array}$ \\
\hline
\end{tabular}

Di awal setiap wawancara, terminologi dan konsep yang umum digunakan dalam aktivitas fisik secara umum dan dalam konteks aktivitas fisik yang berbeda dibahas dan didefinisikan bersama. Ditegaskan bahwa yang dimaksud dengan konsep kegiatan jasmani meliputi segala macam kegiatan jasmani, baik kegiatan yang diselenggarakan seperti pendidikan jasmani dan olah raga tim. Wawancara berlangsung sesuai dengan preferensi peserta: di rumah keluarga, di tempat kerja orang tua, atau di tempat rehabilitasi. Lamanya wawancara bervariasi antara 28 dan 58 menit. Semua wawancara direkam secara digital dan kemudian ditranskrip kata demi kata oleh penulis pertama.

Analisis data menggunakan analisis konten, dengan pengembangan kategori induktif (Elo \& Kyngas, 2008). Setiap wawancara secara keseluruhan dipilih sebagai 
45 | Dena Widyawan ${ }^{1}$

Participation in physical activity for adolescents with disabilities:

Parents' perspective

unit analisis. Konten dianalisis untuk menemukan makna yang mendasari teks tersebut. Transkrip dibaca beberapa kali untuk memberikan gambaran keseluruhan dari konten sebelum analisis. Unit makna yang berkaitan dengan tujuan penelitian ini diidentifikasi dan dipadatkan dan kemudian diberi kode. Kode-kode tersebut dibandingkan dan dikelompokkan berdasarkan kontennya, sehingga persamaan dan perbedaan mengarah pada pengembangan subkategori dan selanjutnya ke kategori umum dan kategori utama melalui abstraksi.

Langkah-langkah berikut diambil untuk mencapai kepercayaan (Lincoln \& Guba, 1985). Verifikasi dan kredibilitas diperoleh dengan pembekalan sejawat di antara penulis selama proses analisis. Kredibilitas analisis selanjutnya dipastikan dengan terlebih dahulu memiliki salah satu transkrip wawancara paling komprehensif yang dianalisis oleh masing-masing penulis secara independen, kemudian bersama-sama membandingkan dan mengkonsolidasikan kode-kode tersebut, setelah itu proses pengkodean disetujui. Setelah itu, penulis pertama menyelesaikan analisis wawancara yang tersisa dalam diskusi yang erat dengan penulis lain. Proses berulang selama analisis memungkinkan mempertanyakan data dari berbagai perspektif dan kompetensi peneliti dalam disabilitas, promosi aktivitas fisik, fisioterapi, dan pendidikan. Kutipan dari orang tua akan disajikan di bagian "Hasil" untuk menggambarkan isi dari analisis induktif dan untuk meningkatkan konfirmasi hasil (Patton. M. Q, 2002) serta untuk mencapai kredibilitas (Graneheim \& Lundman, 2004). Dalam kutipan perwakilan oleh orang tua, kata pengisi yang umum dalam naskah telah diganti dengan elipsis (. . .). Program perangkat lunak Nvivo 11 (QSR International, 2015) digunakan selama analisis.

\section{HASIL DAN PEMBAHASAN}

\section{Hasil Penelitian}

Berdasarkan 776 pernyataan yang sesuai dengan tujuan penelitian ini, analisis induktif menghasilkan tiga kategori utama: (1) kesulitan menangani transisi ke masa remaja, (2) mengidentifikasi hambatan partisipasi remaja dalam aktivitas fisik, dan (3) 
46 | Dena Widyawan ${ }^{1}$

Participation in physical activity for adolescents with disabilities:

Parents' perspective

beban orang tua dalam mempromosikan partisipasi aktivitas fisik (Tabel 2). Deskripsi

beban orang tua menghasilkan pernyataan terbanyak (387) di tingkat kategori utama.

1. Kesulitan menangani transisi ke masa remaja

"Lebih mudah sebelumnya."

Tabel 2. Kategori utama, kategori umum, dan subkategori dari analisis induktif.

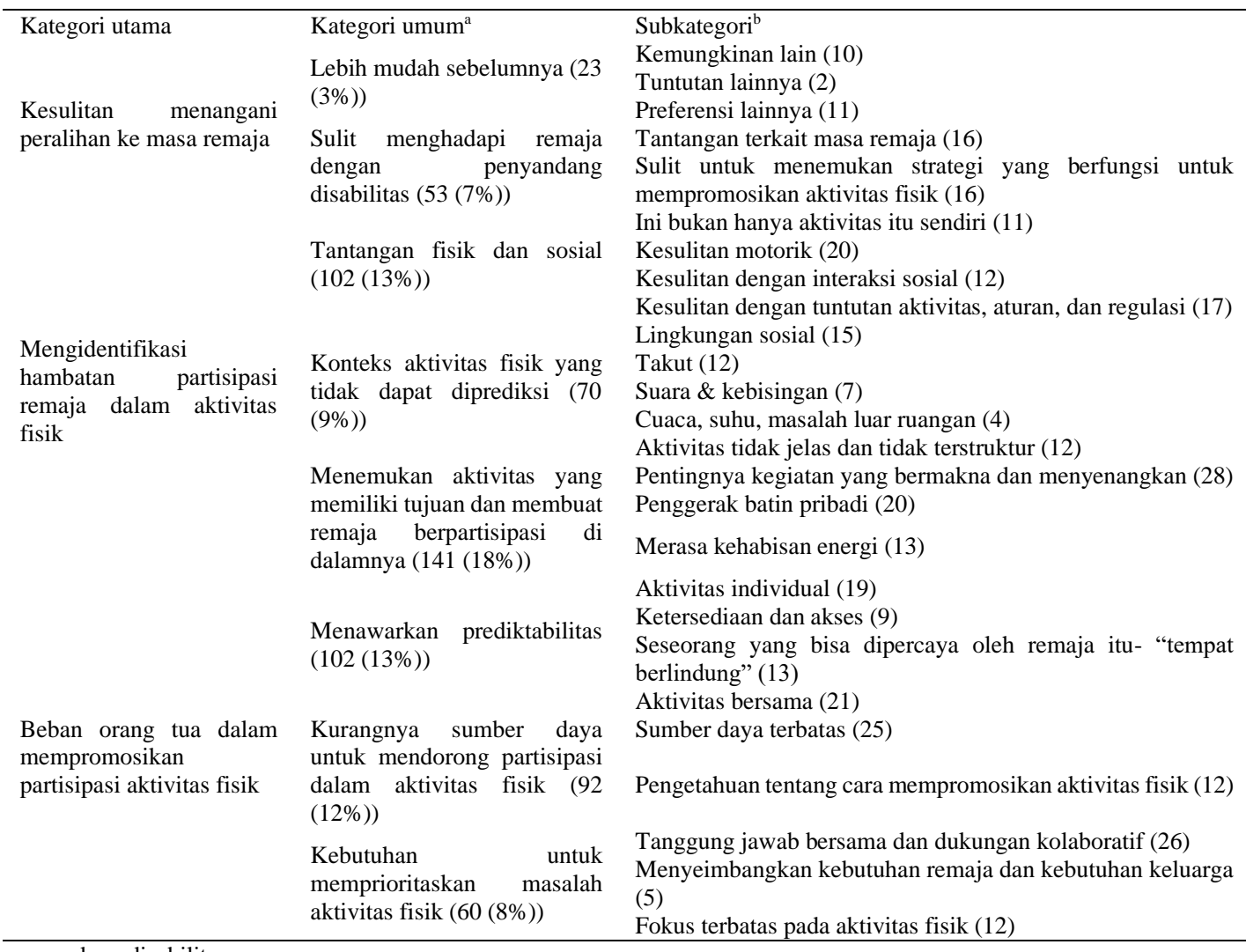

penyandang disabilitas

a Jumlah pernyataan (persentase dari jumlah pernyataan).

bJumlah orang tua yang diwakili di setiap subkategori yang mendemonstrasikan "generalisasi internal" (Maxwell, 2010).

"itu lebih mudah ketika dia masih muda. . . tapi sekarang sulit bahkan untuk membawanya keluar sama sekali. . . Saya tidak tahu apakah itu ada hubungannya dengan usianya. . . dan sekarang dia telah menemukan hal ini tentang komputer" (Ibu, 2).

“... sebelum dia begitu menyukai permainan komputer, dia lebih sering berada di luar ruangan. . . dia lebih sering naik sepeda. . . Namun di sisi lain ia sekarang memiliki kontak yang lebih dekat dengan teman-teman sekelasnya [melalui permainan 
47 | Dena Widyawan ${ }^{1}$

Participation in physical activity for adolescents with disabilities:

Parents' perspective

komputer] dan itu tentu saja juga penting. . . Anda harus hidup dan berkompromi" (Ayah, 5).

"Entah bagaimana anak-anak itu sendiri yang bertanggung jawab, saya kira, begitu mulai mencapai usia itu. . . dan tentu sadar akan perlunya berolahraga, hanya saja beberapa darinya merasa sangat sulit" (ibu, 19).

"Kombinasi penyandang disabilitas dan remaja bisa dengan sendirinya . . jadi ketika Anda kemudian menambahkan aktivitas fisik, itu pasti tidak mudah . .." (ibu, 25).

“ayo, ayo-itu hanya akan memiliki efek sebaliknya” (ayah, 27).

"Saya masih harus berpegang pada pendekatan membujuk . . . itu untuk membuatnya percaya bahwa itu perbuatannya sendiri ... meskipun saya tahu terkadang saya harus menyingkirkan beberapa rintangan terlebih dahulu, yang mungkin tidak dia sadari” (ibu, 12).

2. Mengidentifikasi hambatan partisipasi remaja dalam aktivitas fisik Tantangan fisik dan sosial.

“. . . disabilitasnya sangat mempengaruhinya . . . Artinya, dia memiliki begitu banyak rintangan yang harus diatasi sebelum dia benar-benar dapat mengikuti kegiatan ini atau itu ... jadi ini adalah proses besar yang jauh lebih sulit baginya untuk dikuasai daripada bagi orang lain . . . (ibu, 12)

“. . . tetapi di sekolah, yang terpenting adalah kinerja ... dan dia tidak bisa mengatasi itu, karena harus tampil” (ibu, 12).

"[Olahraga tim] tidak bekerja sama sekali . . Saya pikir itu agak terlalu campur aduk untuknya . . . banyak pemain di lapangan berlari kesana kemari . . dia tidak memahami apa yang seharusnya dia lakukan ... tidak, itu tidak berjalan dengan baik . ..”(Ibu, 12)

"Ada terlalu banyak interaksi dengan orang lain dan itu ternyata sulit . . bukan karena aktivitas itu sendiri, melainkan segala sesuatu di sekitarnya yang terasa mengganggu" (ibu, 1).

"Dia juga sangat kesal ketika ada beberapa aturan dan seseorang tidak mematuhinya . . bahkan hal semacam itu tidak berjalan dengan baik" (ibu, 20). 
48 | Dena Widyawan ${ }^{1}$

Participation in physical activity for adolescents with disabilities:

Parents' perspective

Konteks aktivitas fisik yang tidak dapat diprediksi.

"Dia memiliki tugas di lapangan dan tahu persis apa yang seharusnya dia lakukan dan semua itu ... dia memang memiliki masalah tertentu dengan rekan satu timnya, tapi tidak apa-apa" (ibu, 10).

Menemukan aktivitas yang memiliki tujuan dan membuat remaja berpartisipasi di dalamnya.

"Ada pemandian umum di dekat sekolah jadi sangat nyaman, dan dia suka itu, jadi dia selalu mencoba untuk berpartisipasi di dalamnya . . . dan kemudian dia bahkan bisa mengabaikan konflik . . . dia merasa itu semua menggoda . ..” (ibu, 1).

"Saya agak tidak punya bukti tentang ini, tetapi saya pikir begitu dia menemukan sesuatu yang dia sukai, itu bisa terjadi . . . bermanfaat . . ., bahwa dia bisa memasuki gelembungnya sendiri . . . dan berlatih sendiri tanpa memikirkan orang lain di sekitar. .." (ayah, 7).

"Dia membutuhkan seseorang untuk mengajaknya keluar, seseorang yang dia rasa aman bersamanya. Dia tidak mengambil inisiatif sendiri” (ibu, 24).

"Ini adalah dilema bagi kita sebagai orang tua, kenyataan bahwa ada begitu banyak hal yang kita sebagai orang tua ingin dia lakukan termasuk aktivitas fisik yang kita kenal tetapi tidak punya waktu untuk berolahraga, dan dia hanya tidak memiliki cukup tenaga, karena dia sangat kelelahan setelah seharian di sekolah"(ibu, 26).

3.Beban orang tua dalam mempromosikan partisipasi aktivitas fisik

\section{Menawarkan prediktabilitas.}

"Saya pikir hambatan terbesar adalah ketika dia tidak tahu bagaimana keadaannya, dan kemudian dia mengatakan tidak bahkan sebelum sampai di sana, Maksud saya hanya untuk mengetahui akan seperti apa, bagaimana tampilannya, orang mana yang akan berada di sana . . . bagaimana semuanya direncanakan, dan posisinya sendiri dalam kaitannya dengan yang lainnya ... dan kemudian adil "tidak," maka itu adalah perhentian buntu. Begitulah adanya dengan segalanya . . . yang baru saja dia ketahui”" (ibu, 21).

Mengadvokasi partisipasi yang disesuaikan.

"setiap orang tidak harus melakukan hal yang sama" (ibu, 12).

Volume 11 Nomor 1 Juni Tahun 2021 e-ISSN : 2721-7175 p-ISSN : 2089-2341 
49 | Dena Widyawan ${ }^{1}$

Participation in physical activity for adolescents with disabilities:

Parents' perspective

“tapi ... itu sulit, kamu tahu ... apakah Anda seharusnya menelepon semua pemimpin dan bertanya: apakah Anda sadar akan situasinya? Bagaimana reaksi Anda jika dia menolak untuk mengambil bagian dalam itu atau itu? .. apakah iya atau tidak? ... seberapa fleksibel aturan Anda? Apakah setiap orang harus mengikuti ke surat itu? Nah, apakah mereka sadar akan kebutuhanya?” (ibu, 21).

"Kami mencoba untuk membuatnya terus berjalan dan melakukan hal-hal yang dia suka lakukan dan lakukan ... tetapi jika Anda tidak menginginkannya . . itu pasti terkait dengan disabilitas ... saat Anda mengalami masalah saat terhubung dengan orang lain ... di situlah sangat mengurangi pemilihan kontak yang tersedia" (ibu 16).

"Saya berharap ada kegiatan fisik yang lebih teratur ... untuk membantu menguji olahraga yang berbeda, karena tidak mudah dengan semua penyelidikan ini . . . sebagai orang tua ... untuk memeriksa apakah klub ini atau itu dapat melakukan sesuatu ..." (ibu, 26).

Kurangnya sumber daya untuk mendorong partisipasi dalam aktivitas fisik.

“. . . jadi sebagai orang tua saya tidak bisa mengatasinya. . . Saya tidak berpikir . . . itu cukup bagi kita dengan yang lainnya untuk menjaga kehidupan sehari-hari kita tetap berjalan" (ibu, 25).

Kebutuhan untuk memprioritaskan masalah aktivitas fisik.

“. . . semua konteks olahraga yang mereka [remaja penyandang disabilitas] kunjungi sering, Maksud saya sekolah juga punya tanggung jawab. Yah, hanya pada level yang berbeda, bisa dikatakan begitu . . . merupakan tanggung jawab masyarakat untuk menyediakan sumber daya bagi anak-anak agar dapat melakukan banyak kegiatan olahraga di sekolah" (ibu, 8).

"Kami tidak pernah membahasnya [pertanyaan tentang aktivitas fisik] karena ada hal-hal lain yang lebih mendesak" (ibu, 27).

"Kami telah berjuang cukup baik selama bertahun-tahun ... sama seperti kami bergumul dengan putri kami, yang mengalami beberapa kesulitan tambahan . . . seperti pada fungsi motoriknya . . . jadi hanya itu ambang untuk pergi ke luar . . . itu tidak semudah bagi dia seperti bagi orang lain. .. "(ibu, 8). 
50 | Dena Widyawan ${ }^{1}$

Participation in physical activity for adolescents with disabilities:

Parents' perspective

"Hanya saja perawat itu merasa khawatir bahwa dia tidak ikut serta [aktivitas fisik] . . jadi tanggung jawab jatuh pada saya untuk memperbaikinya” (ibu, 6).

"Saya kira mereka dengan lebih . . . Disebut apakah itu . . gangguan fisik, bahwa mereka mendapatkan lebih banyak bantuan untuk masalah motorik ... tapi saya sebenarnya berpikir mereka telah melupakan anak-anak disabilitas. ..” (ibu, 20).

\section{Pembahasan}

Hasil penelitian ini mengungkapkan kepedulian orang tua dan menyoroti beban orang tua, menunjukkan upaya berkelanjutan untuk meningkatkan mengontrol saat berpartisipasi dalam aktivitas fisik. Ada kesadaran yang sudah ada sebelumnya di antara orang tua bahwa anak remaja membutuhkan berbagai keterampilan untuk dapat berpartisipasi dengan baik dalam aktivitas fisik, tetapi juga tentang tantangan apa yang mungkin dihadapinya. Orang tua mengenali sebagian besar kondisi, kebutuhan, dan keinginan individu yang diungkapkan oleh remaja dan bagaimana hal itu memengaruhi partisipasinya. Lebih lanjut, hasil tersebut secara khusus menarik perhatian pada persepsi kurangnya dukungan kolaboratif dari layanan publik yang relevan dan betapa sulitnya orang tua untuk mengatasinya sendiri.

Para orang tua pada umumnya menginginkan anak remajanya untuk lebih berpartisipasi dalam aktivitas fisik, sejalan dengan temuan penelitian yang berfokus pada pola partisipasi anak-anak yang lebih muda penyandang disabilitas (Simpson et al., 2017). Hal ini mungkin disebabkan oleh tingginya tingkat perilaku menetap dan rendahnya tingkat aktivitas fisik dalam populasi ini, lebih rendah daripada teman yang normal. Namun, pengakuan orang tua atas partisipasi bersyarat anak remaja dalam aktivitas fisik dan keinginan agar lebih sering berpartisipasi memerlukan peningkatan keterlibatannya sendiri. Pendekatan dan strategi yang digambarkan dalam penelitian mencerminkan temuan penelitian sebelumnya tentang bagaimana orang tua dari anakanak penyandang disabilitas mempromosikan partisipasi dalam aktivitas fisik (Obrusnikova \& Miccinello, 2012) dan bagaimana mengelola perilaku anak-anak yang bermasalah (O’Nions et al., 2018). Deskripsi ini mengkonfirmasi temuan (Blagrave \& Colombo-Dougovito, 2019) "perencanaan yang berlebihan" dan pertimbangan 
51 | Dena Widyawan ${ }^{1}$

Participation in physical activity for adolescents with disabilities:

Parents' perspective

keselamatan dianggap penting saat berpartisipasi dalam aktivitas fisik komunitas. Orang tua menyadari perlunya prediktabilitas, tetapi ketidakfleksibelan remaja mengenai rutinitas menempatkan tuntutan tinggi padanya. Orang tua berkomentar bahwa semua persiapan ini dapat memakan waktu dan menjadi beban keuangan, tanpa selalu mengakibatkan peningkatan partisipasi dalam aktivitas fisik. Penelitian sebelumnya menegaskan bahwa dukungan yang diberikan kepada remaja penyandang disabilitas belum tentu cukup efektif untuk mengatasi hambatan yang dirasakan untuk berpartisipasi dalam aktivitas fisik (Pan \& Frey, 2005).

Para orang tua yang memiliki beberapa anak mengamati bahwa dapat melihat bahwa anak remajanya yang penyandang disabilitas membutuhkan lebih banyak dukungan dibandingkan dengan saudara kandung yang normal dalam hal partisipasi aktivitas fisik. Remaja penyandang disabilitas dapat menunjukkan sikap ambivalen untuk memberikan dukungan orang tua selama masa remaja, dan dengan demikian peran orang tua dianggap ambigu, melibatkan keberadaan dan tetap diam-diam dari pandangan. Upaya orang tua untuk mendorong partisipasi dapat digambarkan sebagai lebih besar dan lebih kompleks untuk remaja penyandang disabilitas dibandingkan dengan tuntutan pengasuhan dengan populasi lain (Gregor et al., 2018) menyebutkan ini sebagai persalinan tersembunyi, yang mencakup mengambil peran advokasi untuk meningkatkan partisipasi remaja dalam kegiatan.

Meskipun orang tua dalam penelitian ini dengan jelas mengidentifikasi misi untuk mempromosikan kebiasaan aktivitas fisik yang sehat sebagai tanggung jawab orang tua, beberapa merasa memberatkan. Penelitian yang menunjukkan bahwa orang tua mengalami stres tingkat tinggi sehubungan dengan upayanya untuk memenuhi kebutuhan dan tuntutan remaja penyandang disabilitas, dan untuk mengoordinasikan perawatan dan intervensi dengan layanan public (Karst \& Van Hecke, 2012). Oleh karena itu, orang tua dari remaja penyandang disabilitas mungkin menganggap peningkatan aktivitas fisik remaja sebagai tugas yang berat. Untungnya, orang tua dalam penelitian ini melihat promosi kebiasaan aktivitas fisik yang sehat sebagai tanggung jawab bersama, seperti orang tua, sekolah, masyarakat, dan layanan kesehatan, yang juga ditemukan dalam penelitian sebelumnya (Licence, 2004). 
52 | Dena Widyawan ${ }^{1}$

Participation in physical activity for adolescents with disabilities:

Parents' perspective

Meskipun demikian, kurangnya kesempatan yang tersedia untuk aktivitas fisik dan kurangnya pengetahuan di antara para pemimpin aktivitas mengenai penyandang disabilitas dilaporkan membatasi partisipasi remaja. Hal ini dikonfirmasi oleh penelitian sebelumnya yang menunjukkan bahwa remaja penyandang disabilitas menghadapi lebih banyak hambatan untuk berpartisipasi dalam aktivitas fisik dibandingkan dengan remaja lainnya, dan keluarganya melaporkan lebih banyak tantangan ketika mencoba melibatkannya dalam aktivitas fisik (Blagrave \& ColomboDougovito, 2019). Pendidikan jasmani, misalnya, adalah salah satu konteks utama di mana kebiasaan aktivitas fisik yang sehat dikembangkan tetapi, menurut tanggapan wawancara orang tua dalam penelitian ini, hanya sekitar setengah dari remaja berpartisipasi dalam pendidikan jasmani, meninggalkan beban jasmani yang lebih besar promosi kegiatan orang tua. Beban yang dirasakan lebih besar pada orang tua akibat kurangnya pemahaman dari masyarakat, kurangnya pengetahuan dan pelatihan aktor yang berbeda tentang penyandang disabilitas, dan kurangnya adaptasi dengan kebutuhan individu juga telah dilaporkan dalam penelitian sebelumnya (Gregor et al., 2018). Perlunya strategi untuk mendukung partisipasi dalam aktivitas fisik juga disorot dalam tinjauan sistematis baru-baru ini (Ruggeri et al., 2020).

Hasil wawancara orang tua dengan jelas menunjukkan bahwa promosi kebiasaan beraktivitas fisik yang sehat pada remaja penyandang disabilitas perlu diutamakan, dan bahwa dukungan yang diberikan perlu disesuaikan dengan kebutuhan remaja dan keluarganya. Para orang tua menekankan kurangnya dukungan yang tepat, yang tidak dinyatakan secara jelas oleh remaja penyandang disabilitas sendiri saat diwawancarai dalam penelitian sebelumnya. Kebutuhan akan dukungan yang lebih berpusat pada keluarga sejalan dengan penelitian lain yang melaporkan kebutuhan orang tua untuk lebih banyak dukungan, arahan, dan bimbingan dari para ahli (Gregor et al., 2018). Sebaliknya, kesediaan orang tua untuk mengontrol aktivitas fisik anak yang membawa kemungkinan dan masalah juga tercermin dalam penelitian lain (Healy et al., 2018). Dalam penelitian, terbukti bahwa orang tua yang menyatakan kebutuhan akan dukungan kolaboratif penting karena beban orang tua yang sudah tinggi. Upaya kolaboratif yang disesuaikan secara individu mungkin bermanfaat untuk meningkatkan

Volume 11 Nomor 1 Juni Tahun 2021 e-ISSN : 2721-7175 p-ISSN : 2089-2341 
53 | Dena Widyawan ${ }^{1}$

Participation in physical activity for adolescents with disabilities:

Parents' perspective

partisipasi dalam aktivitas fisik, terutama karena intervensi multikomponen yang mencakup sekolah, keluarga, dan keterlibatan komunitas telah terbukti memiliki potensi untuk membuat perbedaan dalam mengembangkan kebiasaan aktivitas fisik remaja (van Sluijs et al., 2007).

\section{SIMPULAN}

Penelitian ini menggambarkan kebutuhan untuk mengenali kondisi individu untuk partisipasi dalam aktivitas fisik yang diekspresikan remaja penyandang disabilitas. Orang tua sangat menyadari kondisi ini dan mengambil berbagai langkah untuk memberikan anaknya mempunyai rasa kendali yang lebih besar atas partisipasinya. Namun, untuk meningkatkan partisipasi aktivitas fisik di antara remaja penyandang disabilitas, perhatian harus ditingkatkan pada masalah dalam penelitian ini, dan dukungan harus diberikan untuk meringankan beban orang tua.

\section{DAFTAR PUSTAKA}

Afriyuandi, A. R. (2018). Pengaruh Outdoor Education Berlandaskan Experiential Learning Terhadap Kreativitas. Jurnal Maenpo: Jurnal Pendidikan Jasmani Kesehatan Dan Rekreasi, 08(2), 45-55. https://jurnal.unsur.ac.id/maenpo

Ayvazoglu, N. R., Kozub, F. M., Butera, G., \& Murray, M. J. (2015). Determinants and challenges in physical activity participation in families with children with high functioning autism spectrum disorders from a family systems perspective. Research in Developmental Disabilities, 47, 93-105. https://doi.org/10.1016/j.ridd.2015.08.015

Basterfield, L., Adamson, A. J., Frary, J. K., Parkinson, K. N., Pearce, M. S., \& Reilly, J. J. (2011). Longitudinal Study of Physical Activity and Sedentary Behavior in Children. Pediatrics, 127(1), e24-e20. https://doi.org/10.1542/peds.2010-1935

Biddle, S. J. H., \& Asare, M. (2011). Physical activity and mental health in children and adolescents : a review of reviews. British Journal of Sports Medicine, 45(11), 886-895. https://doi.org/10.1136/bjsports-2011-090185

Blagrave, A. J., \& Colombo-Dougovito, A. M. (2019). Experiences Participating in Community Physical Activity by Families with a Child on the Autism Spectrum : a Phenomenological Inquiry. Advances in Neurodevelopmental Disorders (2019), $3(1), 72-84$.

Brinkmann, S., \& Kvale, S. (2015). InterViews: Learning the craft of qualitative research interviewing ( $3 \mathrm{rd}$ ed). Sage, Thousand Oaks.

Cheng, A. L., Mendonc, G., \& Farias Junior, J. C. (2014). Physical activity in 
Participation in physical activity for adolescents with disabilities:

Parents' perspective

adolescents : analysis of the social influence of parents and friends \&. Jornal de Pediatría, 90(1), 35-41. https://doi.org/10.1016/j.jped.2013.05.006

Elo, S., \& Kyngas, H. (2008). The qualitative content analysis process. Journal of Advanced Nursing, 62(1), 107-115. https://doi.org/10.1111/j.13652648.2007.04569.x

Graneheim, U. H., \& Lundman, B. (2004). Qualitative content analysis in nursing research : concepts, procedures and measures to achieve trustworthiness. Nurse Education Today, 24(2), 105-112. https://doi.org/10.1016/j.nedt.2003.10.001

Gregor, S., Bruni, N., Grkinic, P., Schwartz, L., Mcdonald, A., Thille, P., Gabison, S., Gibson, B. E., \& Jachyra, P. (2018). Parents' perspectives of physical activity participation among Canadian adolescents with Autism Spectrum Disorder. Research in Autism Spectrum Disorders, 48, 53-62. https://doi.org/10.1016/j.rasd.2018.01.007

Healy, S., Marchand, G., \& Williams, E. (2018). "I'm not in this alone" the perspective of parents mediating a physical activity intervention for their children with autism spectrum disorder. Research in Developmental Disabilities, 83, 160-167. https://doi.org/10.1016/j.ridd.2018.08.014

Karst, J. S., \& Van Hecke, A. V. (2012). Parent and Family Impact of Autism Spectrum Disorders : A Review and Proposed Model for Intervention Evaluation. Clinical Child and Family Psychology Review, 15(3), 247-277. https://doi.org/10.1007/s10567-012-0119-6

Laksana, G. S., \& Sumirat, D. (2020). Kontribusi Tingkat Kebugaran Jasmani Dan Tingkat Intelegensi Terhadap Penguasaan Gerak Seni Padungdung. Jurnal Maenpo : Jurnal Pendidikan Jasmani Kesehatan Dan Rekreasi, 10(2), 119-129. https://jurnal.unsur.ac.id/maenpo

Licence, K. (2004). Promoting and protecting the health of children and young people. Child: Care, Health and Development, 30(6), 623-635.

Lincoln, Y. S., \& Guba, E. G. (1985). Naturalistic inquiry. Newbury Park, CA: SAGE Publications.

Mccoy, S. M., \& Morgan, K. (2019). Obesity , physical activity , and sedentary behaviors in adolescents with autism spectrum disorder compared with typically developing peers. Autism, 24(2), 1-13. https://doi.org/10.1177/1362361319861579

Nichols, C., Block, M. E., Bishop, J. C., \& Mcintire, B. (2019). Physical activity in young adults with autism spectrum disorder : Parental perceptions of barriers and facilitators. Autism, $\quad 23(6), \quad 1407$. https://doi.org/10.1177/1362361318810221

O’Nions, E., Happé, F., Evers, K., Boonen, H., \& Noens, I. (2018). How do Parents Manage Irritability, Challenging Behaviour, Non- Compliance and Anxiety in Children with Autism Spectrum Disorders? A Meta-Synthesis. Journal of Autism and Developmental Disorders, 48(4), 1272-1286. https://doi.org/10.1007/s10803-017-3361-4

Obrusnikova, I., \& Miccinello, D. L. (2012). Parent Perceptions of Factors Influencing After-School Physical Activity of Children With Autism Spectrum Disorders. 
55 | Dena Widyawan ${ }^{1}$

Participation in physical activity for adolescents with disabilities:

Parents' perspective

Adapted Physical Activity Quarterly, 29(1), 63-80.

Pan, C., \& Frey, G. C. (2005). Identifying Physical Activity Determinants in Youth with Autistic Spectrum Disorders. Journal of Physical Activity and Health, 2(4), 412-422.

Patton. M. Q. (2002). Qualitative research and evaluation methods. Thousand Oaks; Sage Publications.

Potvin, M.-C., Snider, L., Prelock, P., Kehayia, E., \& Wood-Dauphinee, S. (2013). Recreational Participation of Children with High Functioning Autism. Journal of Autism and Developmental Disorders, 43(2), 445-457. https://doi.org/10.1007/s10803-012-1589-6

QSR International. (2015). Nvivo qualitative data analysis software (Version 11).

Ruggeri, A., Dancel, A., Johnson, R., \& Sargent, B. (2020). The effect of motor and physical activity intervention on motor outcomes of children with autism spectrum disorder: A systematic review. Autism, 24(3), 544-568. https://doi.org/10.1177/1362361319885215

Simpson, K., Keen, D., Adams, D., Alston-Knox, C., \& Roberts, J. (2017). Participation of children on the autism spectrum in home, school, and community. Child Care Health Dev, 44(1), 99-107. https://doi.org/10.1111/cch.12483

Solihin, A. O., Ginanjar, A., \& Widyawan, D. (2020). Resiliensi Siswa Tunanetra dalam Kegiatan Olahraga. Jurnal SPORTIF: Jurnal Penelitian Pembelajaran, 6(2), 423-438. https://doi.org/https://doi.org/10.29407/js_unpgri.v6i2.14497 Resiliensi

van Sluijs, E. M. F., Mcminn, A. M., \& Griffin, S. J. (2007). Effectivenessofinterventions topromotephysical activity in children and adolescents: systematic review of controlled trials. British Medical Journal, 335(7622), 703. https://doi.org/10.1136/bmj.39320.843947.BE

Widyawan, D. (2020). Inklusi dalam pendidikan jasmani : perspektif siswa penyandang disabilitas. Jurnal SPORTIF: Jurnal Penelitian Pembelajaran, 6(3), 735-751. https://doi.org/https://doi.org/10.29407/js_unpgri.v6i3.14891

Widyawan, D., Ma'mun, A., Rahely, B., \& Hendrayana, Y. (2020). Parents of students with disabilities views in learning physical education in special needs school. Qualitative Report, 25(4), 924-936. https://nsuworks.nova.edu/tqr/vol25/iss4/3

Widyawan, D., \& Sina, I. (2021). Inclusion in Physical Education in Primary Schools Dena. JUARA: Jurnal Olahraga, 6(1), 64-78. https://doi.org/https://doi.org/10.33222/juara.v6i1.1148

Wigston, C., Falkmer, M., Vaz, S., \& Parsons, R. (2015). Participation in extracurricular activities for children with and without siblings with autism spectrum disorder without siblings with autism spectrum disorder. Developmental $\begin{array}{lll}\text { Neurorehabilitation } & \text { ISSN:, 200(1), }\end{array}$ https://doi.org/10.3109/17518423.2015.1046091 